\title{
O STF COMO ELITE POLÍTICA A PARTIR DAS PRÁTICAS DECISÓRIAS: O PAPEL DA ARGUMENTAÇÃO
}

\section{Wagner Silveira Rezende ${ }^{1}$}

\begin{abstract}
Resumo: Este artigo busca apresentar os juízes do Supremo Tribunal Federal (STF) brasileiro como elite política, e não estritamente jurídica. A defesa desse argumento é possível graças à importância que o órgão vem ocupando no cenário político-democrático brasileiro, desde a Constituição Federal de 1988, e à natureza de suas práticas decisórias. A partir da análise de um caso específico, a $\mathrm{ADI}$ 3510, no que tange às pesquisas com célulastronco embrionárias no Brasil, aponta-se para a natureza de fato social total da decisão, que se apresenta como uma decisão, entre outros fatores, política. A natureza política da decisão se encontra ainda na utilização de argumentos políticos para sua justificação. Esse fluxo de argumentos diversos é possível graças às características da retórica, demonstrando a importância da mesma em processos decisórios. Por fim, pela posição que o órgão ocupa e pela natureza de suas decisões, é possível tematizar a dualidade estruturaagência, tão cara às ciências sociais.
\end{abstract}

Palavras-chave: Supremo Tribunal Federal, elite política; processo decisório.

Resumen: Este artículo tiene como objetivo presentar a los jueces del Tribunal Supremo (STF) de Brasil como una élite política y no jurídica en sentido estricto. La defensa de este argumento es posible gracias a la importancia de que la agencia ha ocupado la política en Brasil, desde la Constitución Federal de 1988, y gracias a la naturaleza de sus prácticas de toma de decisiones. El análisis de un caso particular, el ADI 3510, acerca de la investigación con células-madre embrionarias en Brasil, apunta a la naturaleza del hecho social total de la decisión, que se presenta como una decisión, entre otros factores, política. La naturaleza política de la decisión está todavía en uso en argumentos políticos para su justificación. Esta corriente de los argumentos es posible gracias a las características de la retórica, demostrando su importancia en la toma de decisiones. Por último, la importancia de la agencia y la naturaleza de sus decisiones, hace posible desarrollar el tema de la dualidad estructura-acción, tan caro a las ciencias sociales.

Palabras-clave: Federal Supreme Court; political elite; decision process.

Abstract: This article aims to show the judges of the Supreme Court (STF) as Brazilian political elite, and not strictly legal. The defense of this argument is possible thanks to the importance that the agency has occupied in the brazilian democracy, since the 1988 Federal Constitution, and thanks to the nature of their decision-making practices. From the analysis of a particular case, the ADI 3510, about research with embryonic stem cells in Brazil, points to the nature of total social fact of the decision, which is presented as a decision, among other factors, policy. The political nature of the decision is still in use in political arguments for its justification. This connection of arguments is possible thanks to the rhetoric, demonstrating its importance in decision making. Finally, the important position of the agency and the nature of their decisions, make possible to develop the theme of structure-action duality, so dear to social sciences.

Key-words: Supremo Tribunal Federal; élite política; proceso de decisión.

1 Doutorando em Ciências Sociais pela Universidade Federal de Juiz de Fora (UFJF). E-mail: wsr_ufjf@yahoo.com.br 


\section{INTRODUÇÃO}

Um dos questionamentos fundamentais propostos pelas Ciências Sociais é entender a relação que os indivíduos estabelecem entre si e com as instituições do mundo social. Até que ponto somos absolutamente comandados pelos fatores sociais externos a nossa vontade, e até que ponto podemos efetivamente efetuar nossas escolhas? Ainda, outra questão no que tange à concepção de mundo social dividido entre sistemas (Luhmann) ou campos (Bourdieu): até que ponto tais sistemas se comunicam sem perderem sua identidade? Há efetivamente uma identidade imaculada em cada sistema?

Tendo como base essas questões de fundo, este trabalho se dedica a entender como os juízes do Supremo Tribunal Federal brasileiro se encontram em uma posição de elite, ao mesmo tempo jurídica e política, e, com isso e por isso, conseguem, de alguma maneira, equilibrar a balança estrutura-ação. Ao decidirem casos complexos com base em argumentos extra-jurídicos, tais juízes rompem com a concepção positivista de direito (do direito puro, que se autolegitima e reproduz), e atingem uma margem de liberdade em suas ações decisórias. Contudo, o sistema jurídico continua impondo algumas restrições a essa discricionariedade: há argumentos, como os estritamente religiosos e de caráter pessoal, que não se legitimam para justificar decisões. Essa possibilidade de equilibrar estrutura-agência está relacionada ao caráter retórico da prática decisória do órgão. Assim, são necessárias algumas especificações acerca da retórica. É o que se passa a fazer. Em seguida segue-se a discussão acerca da caracterização do STF como elite política e a decisão sobre a pesquisa com célulastronco para, em seguida e por fim, apresentar a questão da dualidade estruturaagência.

\section{A RETÓRICA ARISTOTÉLICA}

Aristóteles define a retórica como sendo a antiestrofe da dialética ${ }^{2}$. O termo antiestrofe destaca simultaneamente a identidade e a oposição entre a retórica e a dialética. A identidade está no fato de ambas tratarem de conhecimentos comuns a todos e que não pertencem a nenhuma ciência específica. Apesar de possuírem uma natureza lógica comum (ambas são de ordem formal-lógica), dialética e retórica se organizam em relação a seus respectivos fins, diferenciando-se. Dizer que a retórica não

\footnotetext{
${ }^{2}$ A dialética no mundo grego representava o debate entre duas pessoas, com a apresentação de teses e antíteses. A retórica possuía um âmbito maior, pois objetivava o convencimento de um público maior, não restrito à argumentação entre duas pessoas. O sentido original do termo "dialética" refere-se à arte do diálogo (PERELMAN, 2004, p. 4).
} 
pertence a nenhum campo definido é reconhecer que ela demanda um âmbito de conhecimento universal. Com isso, ela pode estabelecer o que é convincente em qualquer caso. De fato, a retórica é aplicada nas mais diversas situações e campos. Ela não pertence a nenhum campo específico do saber.

Aristóteles (1999) pensa na retórica como arte, o que quer dizer que ela possui uma aplicação prático-produtiva. Ou seja, a retórica não se ocupa de objetos que exigem pura contemplação. Ela comporta uma faculdade subjetiva, e o fato de ser tratada como arte faz com que se relacione com a potência de uso dessa faculdade. Assim, o termo arte se refere à correta aplicação do método retórico e não ao êxito do processo (ARISTÓTELES, 1999). De fato, a retórica busca teorizar sobre o que é adequado para convencer. $\mathrm{O}$ convencimento é o que deve ser buscado, mas o primordial é a correta aplicação do método. A tarefa retórica é, pois, reconhecer os meios de convicção mais pertinentes em cada caso (ARISTÓTELES, 1999).

A retórica tem capacidade de persuadir sobre teses contrárias, sendo uma atividade que concerne ao poder, contrária à ética. Essa é a crítica de Platão. O fato de ela ser capaz de convencer sobre algo e seu contrário, faz com que ela não seja uma atividade submetida a qualquer rigor ético. Sendo assim, a retórica estaria submetida a relações de poder. Aristóteles, entretanto, a subordinava à ética, através do apelo à verdade e ao conhecimento (ARISTÓTELES, 1999). Embora possa convencer sobre teses contrárias, Aristóteles postula que não se deve persuadir para o mal, ou para o injusto. É preciso que se conheça tal persuasão para que, uma vez utilizada, ela possa ser refutada em seus próprios termos. Com isto, a retórica não se encontra, em Aristóteles, relegada ao poder, mas sim vinculada à ética.

A retórica se debruça sobre aquilo que parece poder se resolver de dois ou mais modos distintos. Não há deliberação sobre o impossível ou sobre o certo de acontecer. Para que ocorra deliberação e, portanto, retórica, é necessário que não haja certezas ou impossibilidades absolutas. A retórica necessita do provável para se desenvolver. Esse é o terreno onde a aplicação da retórica é fértil e necessária.

Aristóteles aponta para a existência de três gêneros de discurso: o deliberativo (ou político), o judicial e o epidíctico. Cada um desses gêneros possui características, tempo e fim próprios. A deliberação, voltada para o futuro, é baseada no conselho e na dissuasão. Seu fim é o apontamento, pela argumentação, do que é conveniente ou prejudicial. O discurso judicial, baseado na defesa e na acusação, se volta para o passado (para fatos que já ocorreram). Seu fim é o apontamento do justo ou do injusto. Por fim, o discurso epidíctico, baseado no elogio e na censura, se volta para o presente. Seu fim é o apontamento do belo ou do vergonhoso. O elogio e a deliberação, segundo Aristóteles, são discursos de espécies comuns. Isso quer dizer que a troca de algumas 
expressões, ao se apresentar um discurso deliberativo, pode transformá-lo em epidíctico, e vice-versa.

A distinção entre os três gêneros de discurso e a forma específica como cada um deles se estrutura, com seus fins e recursos argumentativos próprios, não impede, contudo, que, na prática argumentativa, as técnicas e recursos de cada um dos gêneros sejam apropriados no contexto de um gênero diverso3. De fato, na prática os gêneros discursivos podem estar presentes no mesmo contexto teórico. Um discurso travado no âmbito judicial não impede que o argumento deliberativo seja utilizado, ou mesmo o epidíctico. Em um tribunal, ao se tratar de questões criminais, é comum que o advogado de defesa promova uma série de elogios a seu cliente (o réu), apontando suas qualidades e virtudes. Essa técnica é própria do discurso epidíctico, no entanto, é usada, frequentemente, no âmbito do discurso judicial. Essa é uma característica essencial da retórica: permitir o fluxo de argumentos de um gênero a outro. É com base nessa propriedade que podemos defender a condição de elite política do STF, em sua faceta pragmática.

É notória a complexidade do projeto retórico aristotélico. A limitada apresentação feita aqui tem o intuito de trazer à tona os elementos que compõem sua retórica, principalmente a comunicabilidade entre os três gêneros discursivos, pois eles foram a grande fonte na qual os pensadores que buscaram resgatar a retórica se basearam para a reconstrução da mesma. Apesar do evidente refinamento filosófico aristotélico acerca da retórica, ele não foi suficiente para impedir que a arte caísse em profundo obscurantismo durante a história do pensamento ocidental.

\section{PRINCIPAIS CRÍTICAS À RETÓRICA}

Há na história do pensamento saberes sujeitados (FOUCAULT, 2005). Saber sujeitado se refere a todo saber que foi considerado de menor relevância, desprovido do que, em cada época, foi considerado como um saber legítimo. Esse tipo de saber foi excluído do horizonte científico como forma legítima de produção de conhecimento.

A retórica é, nesse sentido, um saber sujeitado. A retórica foi tida como um saber desqualificado, pois perdeu o combate travado desde sua crítica por Platão, cujo ápice foi a filosofia do século XVII. Paralelamente à sua exclusão formal do âmbito da ciência, a retórica, de fato, nunca foi excluída, pois sempre esteve como forma de organizar os discursos, científicos ou não. São nesses dois sentidos, portanto, que a

\footnotetext{
3 As linhas de demarcação entre os três gêneros discursivos estão em sobreposição e possuem limites sem nitidez. Com isso, o justo e o verossímil, o honroso e o útil podem ser encontrados em gêneros oratórios diferentes daqueles que eles caracterizam.
} 
retórica foi um saber sujeitado: excluída do projeto científico do ponto de vista formal, enquanto era ocultada no interior desse mesmo projeto. As principais críticas à retórica se encontram no pensamento de Platão, Hobbes e Descartes (embora não sejam as únicas).

A crítica de Platão à retórica era dirigida, primordialmente, para a principal característica da arte retórica: a capacidade de convencer sobre teses contrárias. Platão via nessa característica o grande problema da retórica, que fazia com que a mesma fosse um instrumento de poder, que levaria ao engano. A crítica de Platão se baseava no fato de a retórica ter surgido ligada ao trabalho dos sofistas. E se a retórica era sofística, ela não poderia fornecer nada de positivo. A sofística era percebida como algo destituído de caráter moral, através da qual qualquer causa poderia ser defendida, independente do aspecto ético que a conduz. Para Platão, então, a sofística estava mais para um discurso dos incompetentes do que para a filosofia que ele procurou desenvolver. Contra a retórica e os enganos aos quais ela levava, Platão desenvolveu uma filosofia apodíctica, a metafísica, assentada, na idéia de verdade. Diante disso, toda contrariedade deveria ser excluída (MEYER, 1994).

Hobbes buscou na geometria o método para construir sua ciência do homem. Diante disso, ele procurou, exaustivamente, empregar termos nítidos e inequívocos para o discurso, ao contrário de Aristóteles, que reconheceu a importância da pluralidade de significados que poderiam ser extraídos dos termos comuns. A influência de Galileu fez com que Hobbes perseguisse um raciocínio rigoroso e dedutivo, levando-o a superar a concepção aristotélica de que não se pode alcançar, nas ciências práticas e deliberativas, a certeza que se alcança nas ciências naturais. Ao contrário, Hobbes buscava essa certeza para o campo da ação humana, através de uma fundamentação matemática em relação às investigações da ação humana. Esta busca pela certeza se manifesta como atesta o contrato social, na perseguição por uma exatidão nos termos empregados, influência do nominalismo. De acordo com esse movimento, é a linguagem que permitirá o acordo entre os homens, pois é ela que permite representar o mundo sensível. O problema levantado por Hobbes é que não há uma relação completamente adequada entre as palavras e as coisas do mundo que elas pretendem representar. Diante disso, Hobbes aponta para dois tipos de representação: as definições servem à ciência, enquanto as metáforas funcionam para os meios nãocientíficos (HOBBES, 2004). Por definição, Hobbes entende a palavra polida. Para Hobbes, só podemos conhecer o mundo pelos nomes e representações que damos e fazemos das coisas. Para se chegar a acordos sólidos é preciso que as coisas estejam bem fixas. Por isso, os pactos e os contratos devem ser tanto mais precisamente fixados quanto for possível. 
O contrato é a convenção, o acordo acerca das coisas que foram explicitadas através das palavras. Com isso, as palavras devem ser as mais e nítidas possíveis, reduzindo, ao limite, a ambigüidade. É por isso, por sua maior clareza, que as definições devem ser utilizadas no espaço para o acordo e para o entendimento, sendo, a linguagem baseada na depuração proporcionada pelas definições mais adequada aos contratos. Já as metáforas, por serem ambíguas e carentes de nitidez, não são adequadas para os contratos. O uso das metáforas é muito criticado por Hobbes, e as metáforas são parte fundamental da retórica. De acordo com Hobbes, o pensamento metafórico só pode levar a ilusões. Essa perspectiva tem grande afinidade com a crítica de Platão à retórica, que a via, como uma forma de enganar as pessoas, afastando-as da verdade. A retórica seria, então, o locus do poder e da ilusão, e não da verdade. O passo definitivo dado por Hobbes (2004), que compromete a retórica, é vincular as definições à ciência, ou seja, ciência só se faz através de definições corretas e precisas, excluindo as metáforas deste processo de fazer científico.

Essa busca pelo universal, pelo absolutamente correto e pela certeza matemática, presente no pensamento hobbesiano, atinge seu ápice com René Descartes (TOULMIN, 1994). Descartes é eloquente quanto à sua admiração pelo raciocínio matemático, e quanto aos resultados que ele oferece, "por causa da certeza e evidência de seus raciocínios" (DESCARTES, 2008, p. 17). Descartes centra sua proposta de método em rechaçar tudo aquilo que não é absolutamente certo. Assim, ele dá grande valor à evidência, fazendo dela o marco de referência para a produção do verdadeiro conhecimento. Aliás, o século XVII, representou, no seio da filosofia e da ciência, uma ascensão e um domínio do cartesianismo, que se baseava na evidência, o que levou a um grande descrédito da retórica. Diante disso, Descartes estava pronto a rejeitar qualquer afirmação que não pudesse ser confirmada através de uma evidência confiável. A pluralidade de opiniões, então, se mostrava como algo extremamente problemático, e que deveria ser evitado a todo custo. O que é apenas provável, só pode ser falso. Por isso, Descartes recorre à lógica, à geometria e à álgebra.

Assim, no pensamento cartesiano, onde a certeza e a matemática têm lugar de tão grande destaque, a retórica, e sua característica de tratar dos contrários e do que é provável, não puderam ocupar senão um lugar de rechaço, exclusão e desconfiança. $\mathrm{O}$ cartesianismo parece ter sido o golpe de misericórdia para a retórica, que já vinha sofrendo agressões desde a crítica platônica. (CARRILHO, 1994). A julgar pela força que as idéias de Platão, Hobbes e Descartes tiveram no pensamento ocidental, é possível entender o descrédito da retórica. 


\section{O RESGATE DA RETÓRICA}

No entanto, a retórica, depois de tanto tempo no obscurantismo, volta a ser tratada com uma dignidade própria, se apresentando como uma saída entre o ceticismo e o niilismo, características de um relativismo absoluto, e o apodíctico, matemático e silogístico. Trata-se de dotar a retórica de um caráter de racionalidade em contextos nos quais os debates não podem mais ser evitados. O enfoque da retórica de Perelman é justamente analisar os argumentos que, efetivamente, arquitetam as decisões, rechaçando a concepção de uma linguagem unívoca, e aceitando a multiplicidade. Perelman resgata o pensamento aristotélico, e dá novamente ao silogismo dialético a importância que ele possuía na obra do filósofo grego. Apontando que deliberar e argumentar são faculdades de seres racionais, Perelman encara seu tratado sobre argumentação como "uma ruptura com uma concepção de razão e do raciocínio, oriunda de Descartes, que marcou com seu cunho a filosofia ocidental dos últimos três séculos" (PERELMAN \& OLBRECHTS-TYTECA, 2005, p. 1). Não se trata mais de reduzir, cartesianamente, toda prova à evidência. Se assim fosse, não haveria espaço para uma teoria da argumentação. Contudo, a maioria das decisões é tomada sem base em uma evidência.

Assim, Perelman e Olbrechts-Tyteca, embora se concentrem no modelo retórico aristotélico, acabam por modificar tal modelo, ampliando suas bases, e focando, principalmente, no aspecto argumentativo da retórica (no logos). As paixões e o caráter epidíctico do modelo aristotélico não são tematizados de forma detida nesse projeto dos autores. Perelman está interessado em expandir o caráter argumentativo da retórica, fazendo com que a mesma seja a própria argumentação. Desta forma, ele busca oferecer uma teoria da argumentação que seja capaz de fornecer à lógica o que falta à mesma: uma teoria das decisões às quais as pessoas chegam através de raciocínios somente plausíveis, e não dotados de certeza.

O projeto de Perelman é seguido por Meyer. Para este não há discurso sem retórica. Meyer aponta, contudo, que a nova retórica proposta por Perelman trabalha o logos como sendo somente argumentativo, destituído de paixões. Assim, os aspectos formais de um estilo ornado e o aspecto emocional são disciplinados, quando não esvaziados. Embora Aristóteles tenha sido a grande influência para a retórica proposta por Perelman, aquele mantinha em seu projeto retórico a importância dos aspectos emocionais e das paixões. Em Perelman, ao contrário, o aspecto emocional deixou de ser importante. E Meyer busca manter a importância das paixões no discurso.

O enfoque na retórica proposta por Meyer está na existência de uma pergunta. O problema que se levanta é que permite que a negociação entre os indivíduos se 
estabeleça. Sem uma questão que se coloca, não há debate e nem possibilidade de escolhas contrárias, pois as pessoas teriam um único caminho a seguir e um ponto de vista uniforme. Segundo Meyer (2007), a retórica e a argumentação não podem mais ser pensadas em separado, privilegiando-se uma enquanto se negligencia a outra. Assim, a retórica é uma argumentação condensada. O que se nota com isso é que a retórica possibilita expressar uma idéia, sem que seja necessário explicitar todo o raciocínio. Desta forma, a utilização ora da retórica (condensada), ora da argumentação (sem condensar) pode ser mais oportuna diante da ocasião em que nos encontramos. Contudo, o fim de ambas é o mesmo: convencer.

Stephen Toulmin busca aproximar a lógica da prática cotidiana, e com isso, acaba por aproximá-la da retórica. O que mais nos interessa em sua obra é o estabelecimento de um layout para os argumentos, ou seja, a existência de uma estrutura argumentativa que se faz presente em todos os argumentos. Essa estrutura, portanto, é campo-invariável (se manifestando onde quer que o argumento seja apresentado). Esse layout é um dado metodológico importante para este trabalho, pois permitiu analisar os votos dos ministros do STF, demonstrando a construção retórica dos argumentos. Assim, o modelo padrão de argumento proposto por Toulmin tem a seguinte estrutura (2006, p. 150):

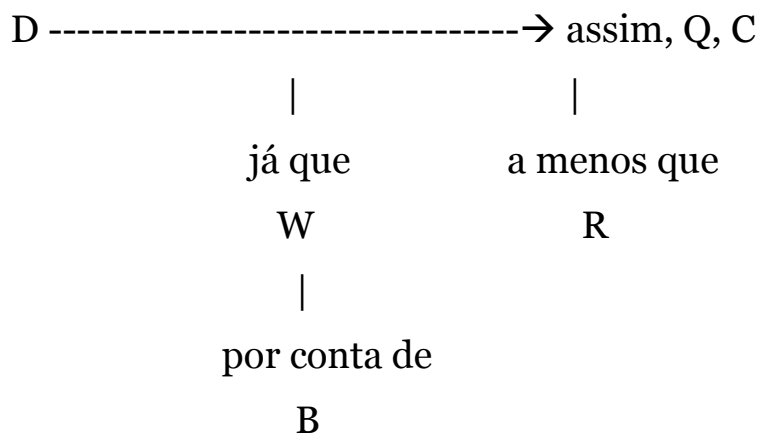

O que se apreende do modelo de argumento estabelecido por Toulmin é que o argumento deve conter: dados (D)4, que são fatos utilizados para fundamentar a alegação ou conclusão (e para Toulmin, em todo argumento é necessário que haja apresentação de alguma forma de dados, pois uma conclusão pura, sem dados de apoio, não se configura como argumento); alegação, ou conclusão (C), que é aquilo que se busca estabelecer, ou seja, aquilo sobre o que se busca convencer; garantias do argumento (W), que conferem força para sustentar as conclusões que justificam; qualificador (Q), que indica a força que a garantia pode conferir (aqui há o uso dos

4 Mantém-se, aqui, a mesma simbologia utilizada por Toulmin em inglês, e mantida pela tradução em português (2006). 
termos modais, como 'quase certo que', 'possivelmente', 'presumivelmente'); as condições de exceção, ou de refutação (R), que demonstram as situações nas quais as garantias (W) não são aplicadas; e, por fim, os apoios das garantias (B), que são fatos, ou afirmações categóricas (TOULMIN, 2006, p. 139-147).

\section{O STF COMO ELITE POLÍTICA E A ADI 3510: A QUESTÃo DA PESQUISA COM CÉLULAS-TRONCO EMBRIONÁRIAS}

Para os fins deste trabalho, entende-se elite 5 no que tange à capacidade de tomada de decisões e ao alcance que essas decisões podem ter. Enquanto elite jurídica, tal caracterização advém da própria posição do órgão na organização do sistema judiciário brasileiro. O STF é o órgão judicial responsável pela guarda da Constituição Federal, e é um tribunal, salvo exceções, como as alegações de (in)constitucionalidade (entre outras), recursal. Ou seja, os conflitos, regra geral, passam por tribunais de primeira e segunda instância para, então, caso o intento de recorrer permaneça, chegar ao conhecimento do Supremo. É um órgão, portanto, de terceira instância. Há ainda a questão, recente, das súmulas vinculantes ${ }^{6}$, através das quais as decisões do STF em certos assuntos, se tornam paradigmáticas e com uma força normativa tal que vincula todas as decisões dos outros tribunais sobre os assuntos já vinculados.

Pode-se pensar nos ministros do STF como elite política em dois sentidos claros (porém, não exaustivos): a) institucional; e b) pragmático, ou praxiológico. No primeiro sentido, os ministros do Supremo podem ser pensados como elite devido à forma como chegam ao cargo: eles são nomeados pelo Presidente da República. Essa nomeação, embora deva ser pautada pelos critérios constitucionais do "notório saber jurídico" e da "reputação ilibada", é uma escolha política. O que isso quer dizer é que embora exista a exigência de critérios técnicos para a nomeação junto ao órgão, tais critérios não são os definidores. Somado a eles, está o critério político, ou seja, a nomeação pelo Presidente. Assim, entre aqueles detentores do saber técnico (muitos deles oriundos de concursos para a magistratura estadual, e até mesmo federal, outros oriundos de concursos para a promotoria e defensoria públicas), há ainda a decisão final. E esta é tomada pelo Presidente da República, depois de aprovada a escolha pela maioria do Senado. Em outras palavras, não é o ingresso por concurso (recrutamento meritocrático e técnico) o caminho para as cadeiras do STF. No segundo sentido, que é aquele que mais nos interessa aqui (não que o primeiro não seja importante), pode-se pensar no STF como

\footnotetext{
5 Não é do interesse deste trabalho em específico por questões também de espaço, discutir as formas de recrutamento e o perfil dos juízes do STF, tema tão caro ao estudo das elites. Tal tema exige outro esforço teórico.

${ }^{6}$ A discussão das súmulas vinculantes não é levada a cabo detidamente neste trabalho por questões de enfoque. A defesa aqui é da caracterização do órgão como elite política.
} 
elite política devido à prática de tomada de suas decisões. Como apontado por Werneck Vianna, o judiciário como um todo, e principalmente a corte constitucional, vêm adquirindo relevância cada vez maior no cenário político e democrático brasileiro, desde a promulgação da Constituição Federal em 1988. A esse processo, através do qual os conflitos sociais e políticos passaram a constituir objeto de decidibilidade dos órgãos do judiciário, Werneck Vianna denominou de judicialização da política (processo este que empresta nome à obra). Mas o que o referido autor apontou como algo em vias de consolidação em 1998 (ano em que a obra foi publicada), já se encontra consolidado atualmente7. Comprova-se tal afirmação pela complexidade dos casos levados à apreciação da corte, como as recentes discussões sobre a descriminalização do aborto de fetos anencéfalos, a demarcação da terra indígena Raposa Serra do Sol, e a discussão acerca da (in)constitucionalidade da pesquisa com células-tronco no Brasil (ADI 3510).

A ADI 3510 foi impetrada pelo Procurador-Geral da República com o intuito de conseguir a declaração de inconstitucionalidade do art. $5^{\circ}$ (que trata da pesquisa com células-tronco no Brasil). da lei 11.105/2005, conhecida como lei de Biossegurança. A ADI é uma Ação Direta de Inconstitucionalidade, e seu efeito, caso seja julgada procedente, é retirar determinada lei do ordenamento devido à sua incompatibilidade com a Constituição Federal. A escolha dessa ADI para análise não foi acaso. O tema discutido pela referida ação envolve elementos que extrapolam o âmbito do direito, dizendo respeito à cultura, religião, biologia, economia, política, naquilo que Mauss (2003) se referiu como fato social total. Além disso, o caso não encontrou nenhuma resposta legal estabelecida em nosso ordenamento jurídico, sendo necessário, portanto, construir uma decisão a partir da argumentação. Por fim, a escolha do STF para análise não significa que decisões jurídicas proferidas por outros tribunais não possam ser analisadas lançando mão dos mesmos recursos teóricos e metodológicos.

No campo jurídico, o juiz tem a obrigação de julgar. Caso o juiz não encontre nada na lei que o faça chegar a uma decisão, ainda assim ele está obrigado a emitir uma decisão sobre o caso que lhe cabe enquanto julgador. Assim, a sentença deve ser emitida em qualquer ocasião, independente da complexidade da lide que a envolve. Com isso, o julgador não pode se eximir de emitir uma sentença. Ela, necessariamente, deve pôr termo ao processo. Sem uma decisão consensual, clara e unívoca sobre o caso em questão (o que no campo jurídico denomina-se como hard cases, ou casos difíceis ${ }^{8}$ ), mas com a obrigação de emitir uma decisão, os julgadores se veem diante da argumentação e da persuasão como a única forma de conduzir o debate. Além da

\footnotetext{
7 O inchaço do judiciário é um problema crônico e conhecido no Brasil, e o STF brasileiro é uma das cortes constitucionais que mais recebem processos por ano no mundo.

8 Segundo Dworkin, os casos difíceis têm lugar "quando uma ação judicial específica não pode ser submetida a uma regra de direito clara, estabelecida de antemão por alguma instituição” (2002, p.127).
} 
obrigação de emitir uma decisão, os juízes devem motivá-la ${ }^{9}$, e torná-la pública. A obrigatoriedade e motivação das sentenças são características que fazem da retórica digna de um terreno ainda mais amplo no campo jurídico. Isso ocorre porque o julgador não pode esperar que uma certeza absoluta sobre a questão apareça em todos os casos para emitir um juízo decisório. As decisões são tomadas com base nas informações disponíveis, e estão sujeitas ao convencimento dos juízes acerca dos argumentos que lhe são apresentados contra e a favor de dado tema. Como, regra geral, as certezas não se apresentam, é com base na plausibilidade que as decisões são tomadas.

Para análise, escolhemos, então (por questões de espaço), a petição inicial ${ }^{10}$ do Procurador-Geral da República, os votos dos ministros Marco Aurélio (voto pela constitucionalidade da lei) e Ricardo Lewandowski (voto pela inconstitucionalidade).

O layout do argumento do Procurador-Geral da República (PGR), à época, Cláudio Fonteles, é o que se segue:

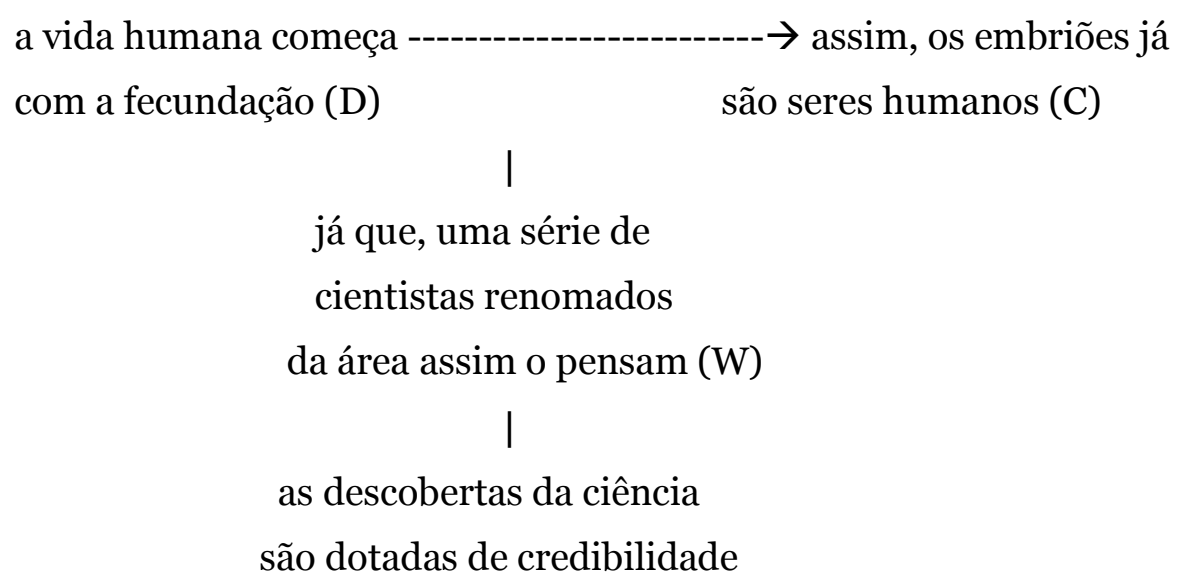

O que a análise do argumento do PGR nos permite perceber é o recurso à autoridade do argumento científico. $\mathrm{O}$ argumento de autoridade, recurso retórico, lança mão do ethos de quem emite o argumento, ou seja, atribui força ao argumento devido à autoridade daquele que construiu o argumento. No caso do PGR, o recurso foi recorrer à autoridade de biólogos e médicos especializados no assunto em debate, qual seja, a pesquisa com as células-tronco embrionárias. Durante a construção de seu argumento,

9 O art. 93, inciso IX, da Constituição de 1988 tornou explícita a obrigatoriedade da motivação das decisões judiciais.

${ }^{10}$ A petição inicial é a peça que inaugura o processo; é o ato primeiro, que dá início ao procedimento. Nela se manifesta a pretensão do autor da ação, ou seja, o pedido, aquilo que se quer do Poder Judiciário. Na definição de Theodoro Júnior, sobre a petição inicial: "o veículo de manifestação formal da demanda é a petição inicial, que revela ao juiz a lide e contém o pedido da providência jurisdicional, frente ao réu, que o autor julga necessária para compor o litígio" (THEODORO JUNIOR, 2005, p. 325). 
o procurador, sucessivamente, procede a citações de especialistas, reforçando a qualificação dos mesmos fazendo referência às suas titulações, como nos exemplos: " $A$ Dra. Elisabeth Kipman Cerqueira, perita em sexualidade humana e especialista em logoterapia..." (p. 5 da petição inicial); "O Professor Titular de Cirurgia da Universidade Autônoma de Madri, Dr. Damian Garcia-Olmo...” (p. 7 da petição inicial); e "A Dra. Cláudia M. C. Batista, Professora-Adjunta da UFRJ e pósdoutorada pela University of Toronto na área de células-tronco afirma (...)” (p. 10 da inicial). Todas essas referências foram seguidas por extensas citações acerca dos elementos biológicos que envolvem as pesquisas com as células-tronco embrionárias.

Assim, ao fazer uso da autoridade destes cientistas, o PGR buscou convencer os ministros julgadores da necessidade de reconhecer a autoridade e a competência dos mesmos em relação ao tema debatido, especialistas que são no assunto. Com isso, o que o procurador fez foi lançar mão de argumentos biológicos e médicos, portanto, externos ao campo jurídico, para fundamentar sua tentativa de conseguir uma decisão favorável à causa que pleiteava (no caso, a declaração de inconstitucionalidade da lei 11.105). Esta decisão tem caráter jurídico, mas sua fundamentação acaba por envolver elementos de outra natureza, como se vê na argumentação estruturada e exposta na petição inicial. Com isso, o argumento que vê não é estritamente jurídico, e sim médico-biológico. É sobre esta argumentação que os ministros se debruçaram para procederem à votação que decidiu sobre a constitucionalidade da pesquisa com células-tronco embrionárias no país. Passemos, pois, à análise de alguns destes votos.

O layout do argumento geral do ministro Marco Aurélio é o que se segue:

a lei 11.105 é dotada de razoabilidade, permitirá a cura de doenças, está em harmonia com a Constituicão Federal, e não atenta contra o direito à vida (D)

já que assim o garantem, a maioria da população, os legisladores que promulgaram a lei, e o mundo especializado da ciência 
Esse argumento geral pode ser repartido em um argumento pontual, que nos interessa:

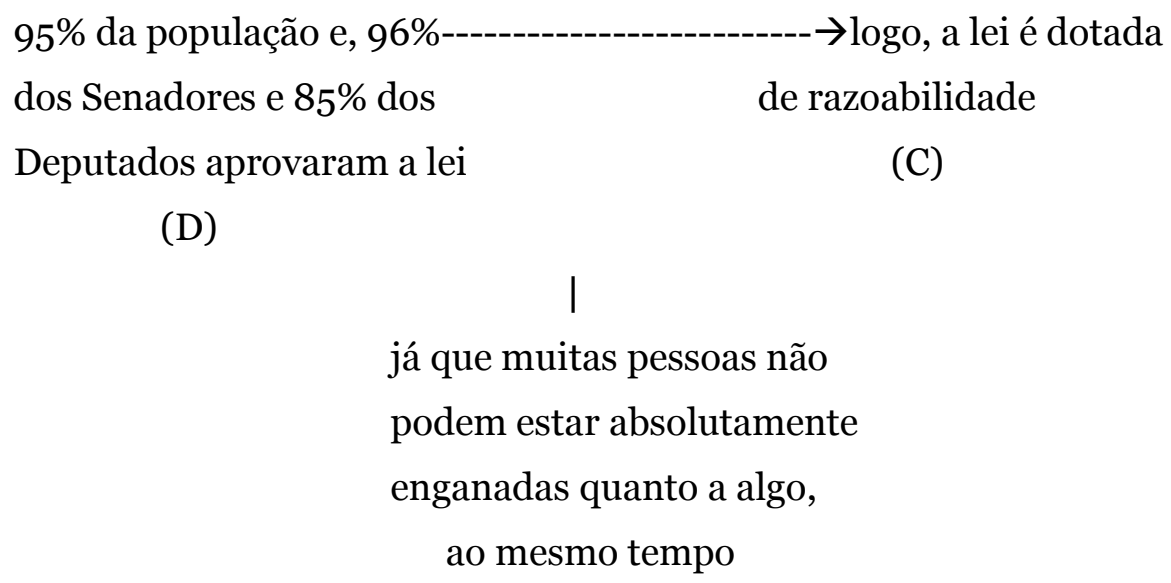

(W)

O que o layout do argumento do ministro permite mostrar é o lançar-mão de um argumento político para justificar e fundamentar uma decisão jurídica. Mesmo sem declarar explicitamente a utilização de uma concepção política rousseauniana, o ministro Marco Aurélio se vale de uma idéia de soberania popular que remonta a Rousseau (2004). Assim, se a população em geral, e os congressistas (representantes do povo) em particular, aprovaram a lei de Biossegurança, então tal lei é dotada de legitimidade, e, portanto, é constitucional.

O ministro Ricardo Lewandowski, ao contrário do ministro Marco Aurélio, votou contra a pesquisa com células-tronco no Brasil, da forma como está sendo tratada pela lei de Biossegurança. Portanto, seu voto foi no sentido da inconstitucionalidade da referida lei (já votou pela constitucionalidade, mas com ressalvas). Apesar de seu voto ter sido contrário ao do ministro Marco Aurélio, Lewandowski também se valeu de argumentos externos ao campo do direito para justificar seu voto. Ao apontar para a insuficiente proteção oferecida pela lei 11.105, no tratamento das pesquisas com células embrionárias, assim se apresenta o layout do voto do ministro Lewandowski:

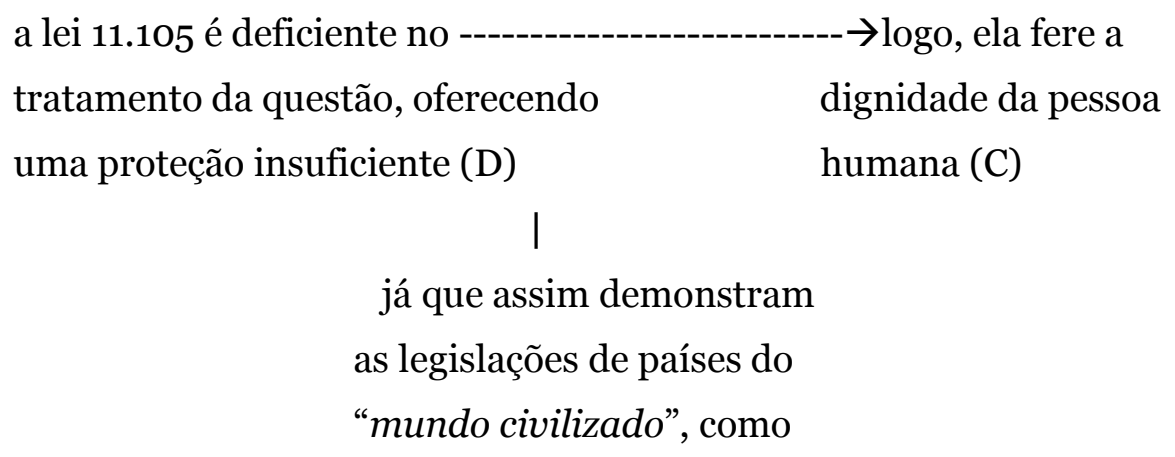


França, Alemanha, Espanha,

Estados Unidos e Países Baixos

(W)

Ao lançar mão do exemplo de outros países, que o ministro tratou como o "mundo civilizado", Lewandwski se vale de um argumento de política de desenvolvimento comparado. Assim, se os países mais desenvolvidos do mundo tratam a questão com certo rigor, o Brasil, se quiser atingir esse patamar de desenvolvimento, deve buscar tratar deste assunto com rigor comparativo, para assim se colocar, pelo menos no que tange à questão, no mesmo patamar que o "mundo civilizado". Mas, além disso, há outro elemento argumentativo que chama a atenção no voto do ministro Lewandowski. Outro argumento do ministro para justificar seu voto pela inconstitucionalidade da lei de Biossegurança na forma como se apresenta no Brasil é o seguinte:

\author{
a ciência, por si, não ---------------------------------- $\rightarrow$ logo, é preciso rigor \\ traz somente benefícios \\ ético no tratamento das \\ à humanidade; ela pode \\ pesquisas com células- \\ ser também prejudicial \\ tronco $(\mathrm{C})$ \\ (D) \\ sob pena de um futuro \\ nada promissor para a \\ humanidade \\ já que assim o demonstram os \\ os exemplos das Guerras mundiais, \\ da destruição do meio ambiente, $\mathrm{e}$ \\ das previsões terríveis, na literatura, \\ de autores como Huxley, Orwell e Kafka (W)
}

Essa crítica aos efeitos que podem ser gerados pela ciência tem o fulcro de fazer com que os defensores mais assíduos das pesquisas com células-tronco, que acreditam nos benefícios que as mesmas trarão, pensem mais refletidamente acerca do projeto que estão defendendo, e dos efeitos danosos que podem advir dele. Diante de um quadro de desenvolvimento tecnológico acentuado, onde os limites ainda não foram estabelecidos, Lewandowski se preocupa com a postura ética a ser adotada diante da proteção do que chamou de direitos de quarta geração (ou seja, aqueles decorrentes dos 
avanços tecnológicos e da bioengenharia), e lança mão de um argumento ad terrorem para prever um possível futuro devastador e preocupante ${ }^{11}$ para a humanidade, caso os avanços tecnológicos não sejam acompanhados por uma regulação ética e jurídica. Para sustentar esse argumento ad terrorem, Lewandowski recorre aos exemplos da literatura: Admirável mundo novo, de Aldous Huxley; 1984, de George Orwell; e $O$ processo, de Kafka (p. 12 do voto). Desta maneira, é recorrendo à literatura que Lewandowski busca convencer seus pares dos prejuízos que podem advir das pesquisas com células-tronco, caso as mesmas não sejam autorizadas sem se observar uma série de preceitos éticos, como ele considera ser o caso da lei 11.105. Assim como Lewndowski recorreu à literatura e a um argumento de política comparativa para fundamentar seu voto, o Procurador-Geral da República recorreu a argumentos de caráter médico-biológico, e o ministro Marco Aurélio a um argumento de ares rousseaunianos.

\section{ESTRUTURA E AGÊNCIA}

A dualidade estrutura-ação é um dos grandes temas das Ciências Sociais. Há defensores do pólo da estrutura (macrossociologia) e do pólo da ação (microssociologia). Há também aqueles que buscam construir formas de ligar estes dois pólos; o foco na ação busca compreender o mundo social a partir de ações individuais, baseando-se em indivíduos reais e concretos. Já o enfoque na estrutura busca explicar a ação dos indivíduos através da existência de estruturas anteriores e superiores aos indivíduos. Assim, por esta última perspectiva, os indivíduos são encarados de forma abstrata. Este tema (estrutura-ação) já se encontra na obra dos clássicos em Ciências Sociais. Enquanto Max Weber pode ser localizado, regra geral, no pólo da ação (portanto, fazendo microssociologia), Karl Marx e Émile Durkheim podem ser localizados como macrossociólogos. O problema de se focar na estrutura ou na ação individual é tão relevante para a sociologia que, pode-se dizer que a pesquisa sociológica, em algum momento, acaba tendo que se debruçar sobre ele.

Tanto quanto esta polarização, chamam a atenção também as tentativas de se construir mecanismos de comunicação entre o foco na estrutura e o foco na ação individual. Neste sentido, encontramos a teoria de Talcott Parsons sobre o sistema social, a teoria do habitus de Pierre Bourdieu, a teoria da estruturação de Anthony Giddens, por exemplo. Estes autores buscaram, nem sempre de forma absolutamente bem sucedida, um compromisso entre a estrutura e a ação.

\footnotetext{
${ }^{11}$ Eis aqui um argumento pragmático, onde o ministro Lewandowski se vale das possíveis consequências futuras de um ato, no caso, conseqüências nefastas, para atribuir a mesma carga emocional e o mesmo valor às causas.
} 
Entender o que significa essa dualidade, em linhas gerais, determina o enfoque dado para a análise do fenômeno social como um todo. A cultura, por exemplo, é uma categoria da macrossociologia. Pode-se entender que os indivíduos agem de acordo com uma cultura específica. Agir de acordo com valores culturais reduz a margem de atuação individual. É como se os indivíduos fossem, todo o tempo, condicionados por uma estrutura anterior e maior do que eles. Assim, constrangidos por esta estrutura, a ação individual teria seu espaço muito reduzido, e as escolhas dos indivíduos seriam mera reprodução desses constrangimentos estruturais. Essa é a perspectiva do ponto de vista da análise focada unicamente na estrutura. Por outro lado, no plano de análise microssociológica, o entendimento é que os indivíduos, racionais, conscientes e pensantes o tempo todo, são capazes de instrumentalizar suas posições na sociedade objetivamente dadas, tendo, portanto, grande capacidade de escolha e não sendo absolutamente conformados em uma estrutura que lhes é anterior. A questão que se coloca, portanto, é: ênfase no ator ou nas estruturas? Há margem de liberdade para a ação individual ou os indivíduos são determinados pelas estruturas, sem liberdade de agir? Afinal, faz ou não diferença a ação do indivíduo?

Para a teoria dos sistemas, não. As teorias sistêmicas, localizadas na polaridade da estrutura e, portanto, de cunho macrossociológico, entendem que os indivíduos não são capazes de determinar suas ações no mundo, pois há uma estrutura muito maior. Com isso, as escolhas individuais fazem pouca diferença. O alemão Niklas Luhmann foi um dos grandes nomes da teoria sistêmica. Luhmann pensou na sociedade como um grande sistema, composto por subssistemas, com estruturas e regras próprias que organizam o mundo. Assim, o direito, a política, a economia, são todos sistemas da sociedade, e cada um deles possui regras internas, códigos, e até mesmo uma linguagem própria. Diante disso, frente a uma organização social do tipo sistêmica, as ações individuais possuem pouca relevância, visto que a estrutura tem um poder condicionante muito grande. A estrutura possui uma lógica de funcionamento própria e se reproduz com pouca influência da ação individual. A questão se coloca no procedimento da estrutura. Essa concepção sistêmica de Luhmann assumiu um papel muito importante para a teoria do direito. É nesse ponto que ela mais nos interessa. $\mathrm{O}$ direito foi pensado, por grande parte da tradição jurídica, como um sistema autopoiético, ou seja, capaz de criar as próprias condições internas de sua reprodução. Assim, o direito seria dotado de um código interno, e os elementos externos que por ventura invadissem o sistema jurídico poderiam ser muito prejudiciais à identidade do mesmo, desconfigurando-o. Diante disso, dentro do sistema jurídico, somente o código jurídico deveria exercer sua força. Essa concepção, levando em conta o ponto de vista da argumentação, significa que somente os argumentos jurídicos deveriam justificar 
decisões jurídicas, para que a identidade interna do sistema fosse mantida. Os argumentos externos, justamente por não pertencerem ao direito, deveriam ser rechaçados para o bom funcionamento do sistema. Desta forma, o sistema constrangeria os julgadores para que suas decisões seguissem os padrões estabelecidos pelo sistema jurídico, ou seja, mantendo o código do direito e fundamentando decisões com base em uma argumentação jurídica, lançando mão de argumentos jurídicos, sem muito espaço para a ação individual dos julgadores. É o caso do positivismo jurídico que, embora há muito questionado do ponto de vista teórico, continua exercendo efeitos práticos no direito. O que o estudo de casos como o aqui analisado nos permite entender, contudo, é que, diante de situações onde o sistema jurídico não autoriza uma decisão correta, imediata, pronta e indubitável, o sistema não pode exigir regras inflexíveis de procedimento, sob pena de se engessar e não permitir que, no caso do sistema jurídico, por exemplo, uma decisão seja tomada. Assim, a ação individual dos julgadores não pode ser pensada como algo irrelevante, cuja incidência não altera o funcionamento do sistema. No caso das células-tronco, por exemplo, a ação dos julgadores é que permitiu que a discussão sobre a (in)constitucionalidade das pesquisas encontrasse termo. Ao lançarem mão de argumentos externos ao direito, visto que o próprio direito tomado como sistema não oferecia uma resposta para a lide, os juízes do STF, através de sua ação, alteraram o sistema, reconfigurando-o. Sem nada no direito a que pudessem recorrer, os juízes foram encontrar em outros setores sociais a possibilidade de julgar a questão, motivando sua decisão e buscando convencer seus pares. Com isso, foi a argumentação baseada em elementos externos ao direito que permitiu que a decisão fosse alcançada.

O que esse estudo nos mostra é, portanto, a atuação de julgadores, tomados como atores racionais que, embora fossem constrangidos pela estrutura do sistema, acabaram por recorrer a elementos que não faziam parte desse mesmo sistema para chegarem a uma decisão. Nesse sentido, encontramos um equilíbrio entre o pólo da estrutura e o pólo da agência, ou seja, da ação. De fato, a estrutura não foi absolutamente rompida e os juízes não agiram absolutamente livres de constrangimentos sistêmicos. Nesse ponto, vale notar, por exemplo, que caso algum dos ministros do STF justificasse seu voto, em qualquer direção que fosse, com base em argumentos de cunho estritamente religioso, certamente enfrentaria problemas para justificar sua decisão. Contudo, por outro lado, mesmo com a incidência dos constrangimentos por parte do sistema, que sem dúvida oferece limites para a ação dos indivíduos, estes não se manifestam de maneira absoluta, deixando espaço, assim, para certa liberdade de tomada de decisão por parte dos juízes. 


\section{CONCLUSÃO}

A análise da decisão do STF acerca da constitucionalidade da pesquisa com células-tronco embrionárias no Brasil nos permite analisar, avaliar e entender uma série de pontos. Primeiramente, nota-se a importância da retórica em contextos decisórios. Valorizada por Aristóteles, mas severamente criticada pela tradição ocidental, o que levou a seu descrédito secular, a retórica aparece, no entanto, como peça-chave na modernidade. Em situações onde a certeza não se afigura no horizonte decisório, é através da argumentação que a decisão se faz possível, enfrentando o terreno do duvidoso. Em seguida, a análise da atuação prática-decisória dos ministros do STF nos permite compreendê-los como elite política, no sentido em que suas decisões ultrapassam o âmbito estritamente jurídico e são justificadas como base em argumentos políticos, entre outros de natureza outra. Além disso, a retórica, no caso aqui analisado, nos fornece elementos para compreender as relações entre estrutura e agência no contexto jurídico. Ao se valerem da possibilidade de recondução de argumentos não jurídicos para contextos jurídicos, característica fundamental da retórica, os juízes do STF dão vazão a sua liberdade decisória confrontada com os limites estabelecidos pelo sistema jurídico. O direito, entendido como sistema nos moldes luhmannianos, prevê decisões fundamentadas em códigos internos ao próprio direito. No entanto, quando o sistema jurídico não fornece uma decisão pronta para a solução do conflito (hard cases), como no caso das células-tronco, essa solução precisa ser construída argumentativamente, e os argumentos para tal são buscados em contextos externos, mas não absolutamente estranhos ao direito, como a política, a literatura, a biologia, etc. Desta forma, percebe-se um compromisso entre estrutura e agência no âmbito da decisão judicial. A decisão não é absolutamente livre, a ponto de qualquer justificativa para a decisão ser aceita, mas também não é absolutamente determinada pelos moldes do sistema, a ponto de os juízes não terem liberdade decisória alguma. Esse compromisso entre estrutura e agência é permitido graças às características da argumentação, permitindo que ocorra um fluxo de argumentos entre o direito e o que é externo ao sistema jurídico, sem com isso comprometer a autonomia do sistema jurídico. Assim, através de sua posição de elite jurídica e política, as decisões do STF nos hard cases nos fornece elementos para compreender até que ponto os sistemas sociais se comunicam sem perderem suas características. E isso ocorre através de um canal muito importante (embora não o único) e frequentemente negligenciado: a retórica. 


\section{BIBLIOGRAFIA}

ARISTÓTELES. Retórica. Editorial Gredos: Madrid, 1999.

BERGER, Peter L. \& LUCKMANN, Thomas. A construção social da realidade. Vozes: Petrópolis, 2009.

BOURDIEU, Pierre. A distinção. Edusp: São Paulo, 2008.

DESCARTES, René. Discurso sobre o método. Editora Vozes: Petrópolis, 2008.

DWORKIN, Ronald. Levando os direitos a sério. Martins fontes: São Paulo, 2002.

FERRAZ JUNIOR, Tércio Sampaio. Introdução ao estudo do direito. Técnica, decisão, dominação. Atlas: São Paulo, 1989.

FOUCAULT, Michel. Em defesa da sociedade. Martins Fontes: São Paulo, 2005.

GIDDENS, Anthony. A constituição da sociedade. Martins Fontes: São Paulo, 2009.

HACKING, Ian. Por que a linguagem interessa à filosofia? Editora Unesp: São Paulo, 1999.

HOBBES, Thomas. Leviatã, ou matéria, forma e poder de um estado eclesiástico e civil. Martin Claret: São Paulo, 2004.

KELSEN, Hans. Teoria pura do direito. $7^{\mathrm{a}}$ edição. Martins Fontes: São Paulo, 2006.

LATOUR, Bruno. Jamais fomos modernos. Ensaio de antropologia simétrica. Editora 34: Rio de janeiro, 1994.

LEVINE, Donald. Visões da tradição sociológica. Jorge Zahar Editor: Rio de Janeiro, 1997.

LUHMANN, Niklas. Introdução à teoria dos sistemas. Editora Vozes: Petrópolis, 2009.

MAUSS, Marcel. Sociologia e Antropologia. Cosac Naif: São Paulo, 2003.

MEYER, Michel. A retórica. Editora Ática: São Paulo, 2007.

As bases da retórica. In: CARRILHO, Manuel Maria (organizador). Retórica e comunicação. Edições Asa: Coimbra, 1994.

PERELMAN, Chäim. Retóricas. Martins Fontes: São Paulo, 2004.

PERELMAN, Chäim \& OLBRECHTS-TYTECA, Lucie. Tratado de Argumentação: A nova retórica. Martins Fontes: São Paulo, 2005.

RIBEIRO, Renato Janine. Ao leitor sem medo - Hobbes escrevendo contra seu tempo. Editora UFMG: Belo Horizonte, 1999.

ROUSSEAU, Jean-Jacques. Do contrato social. Martins Fontes: São Paulo, 2006. 
THEODORO JÚNIOR, Humberto. Curso de Direito Processual Civil, Vol. I. $48^{a}$ Edição. Editora Forense: Rio de Janeiro, 2005.

TOULMIN, Stephen E. Os usos do argumento. Martins Fontes: São Paulo, 2006.

Racionalidade e razoabilidade. In: CARRILHO, Manuel Maria (organizador). Retórica e comunicação. Edições Asa: Coimbra, 1994.

VIANNA, Luiz Werneck; CARVALHO, Maria Alice Rezende de; CUNHA MELO, Manuel Palácios; BURGOS, Marcelo Baumman. A judicialização da política e das relações sociais no Brasil. Editora Revan: Rio de Janeiro, 1999.

www.stf.gov.br 